\title{
EVALUATING STRESS AMELIORATION OF ORAL VITAMIN C IN BUCKS EXPOSED TO LONG TERM ROAD TRANSPORTATION AND STOCKING
}

\author{
K. T. Biobaku ${ }^{1 *}$, B. M. Agaie $^{2}$ and A. Aremu ${ }^{1}$ \\ ${ }^{1}$ Department of Veterinary Pharmacology and Toxicology, University of Ilorin, Ilorin, Nigeria; ${ }^{2}$ Department of \\ Veterinary Pharmacology and Toxicology, Usmanu Danfodiyo University, Sokoto, Nigeria.
}

\begin{abstract}
Forty-eight apparently healthy Sahel bucks were used in this study; sixteen were at high stocking, sixteen bucks at low stocking and sixteen not transported considered as control. Stress of transportation was induced by transporting animals from Sokoto, NorthWestern Nigeria to Abeokuta, South-Western Nigeria. Haematological and some biochemical parameters including stress biomarkers such as glutathione-S-transferase, superoxide dismutase (SOD), malondialdehyde (MDA) and thyroid hormones; triiodothyronine (T3) and tetraiodothyronine (T4) were assessed. There was a significant $(\mathrm{P}<0.05)$ increase in AST, ESR at low stocking and significantly $(\mathrm{P}<0.05)$ increased in percentages of neutrophils at high stocking rate. Lymphocytes and eosinophils significantly $(\mathrm{P}<0.05)$ increased at low stocking rates. $\mathrm{N}: \mathrm{L}$ and monocytes significantly $(\mathrm{P}<0.05)$ decreased at low stocking. Conclusively, ascorbic acid improved recovery from general adaptive syndrome of long transportation at low stocking when welfare regulation is enforced, when compare to high stocking.
\end{abstract}

Keywords: Bucks, stress, ascorbic acid and stocking.

INTRODUCTION

Ascorbic acid is a highly labile chemical substance that is oxidized by an enzyme dehydroascorbate reductase endogenously at metabolism (Bender, 1992). Several studies have demonstrated the effect of ascorbic acid on biochemical and other signs of various types of stress, such as in birds and other animals (Nakano and Suzuki, 1984; Ayo et al., 2006). Stress provokes significant rise in the serum level of ascorbic acid, and a reduction in its concentration in skin, lungs and adrenal glands (Zulkifli et al., 2000). Ascorbic acid is used as an immunomodulator in goats during transportation and it improves electrolytes balance in long term transportation in goats (Minka and Ayo, 2010). Supplementation of ascorbic acid was reported to prevent muscular soreness and improved biochemical parameters following transportation in goats (Minka and Ayo, 2010). The same workers also found that supplementation with vitamin $\mathrm{C}$ could be of utmost economic importance in the meat industries and to stakeholders in the livestock production in developing countries where standard abattoirs and slaughter houses are designated with lairages for resting transported animals are either lacking or the animal welfare laws are not enforced. Stress would affect the health of transported animals and their meat products, which could be detrimental to the health of consumers (Biobaku et al., 2016a).Vitamin C was used previously in the treatment of chronic dermatologic infection in calves (Hidiroglou et al., 1996); it had also been reported to increase plasma and seminal ascorbate which could also improve fertility in small ruminants (Hidiroglou et al., 1997).With the aforementioned therapeutic and nutritional uses of vitamin $C$ in animals. This study is aimed at evaluating the anti-stress effect of ascorbic acid in long term transportation of 28 hours in Sahel bucks exposed at different stocking rates (high and low) using some biochemical and haematological parameters.

\section{MATERIALS AND METODS}

Experimental animals and management

Forty-eight apparently healthy Sahel bucks were used in this study. Their ages were in the range of one and half and two years and were of the weight range of 12-15 Kg with universal body condition score of 3 . The animals were procured from livestock markets in Tangaza, Gada, Kware and Achida of Sokoto state. The bucks were fed on groundnut hay and cowpea husk and given clean water ad libitum. They were prophylactic treated using albendazole (Albenzole, Agbara Industries, Lagos, Nigeria) and a combination of penicillin and streptomycin (Penstreptomycin ${ }^{\circledR}$, Kepro, Holland). They were acclimatized for two weeks and were certified healthy by a veterinarian from the Sokoto State Ministry of Forestry and Animal Health. The bucks were neither tethered nor restrained in any other way and were stocked at rate of $2 \mathrm{~m}$ square per goat in the pen.

*Corresponding e-mail address: biobaku.kt@unilorin.edu.ng

Copyright () 2017 Bangladesh Society for Veterinary Medicine

All rights reserved 0395/2017 


\section{K. T. Biobaku and others}

\section{Induction of transportation stress}

Stress of transportation was induced by transporting animals from Sokoto, North-Western Nigeria to Abeokuta, South-Western Nigeria. This distance was chosen because in real life situation a preliminary showed this is among the most frequently followed route by marketers involved in livestock transportation. The total distance travelled was about $969 \mathrm{~km}$ at a speed of $40 \mathrm{~km} / \mathrm{hr}$ as previously carried out by Biobaku et al. (2016a).

\section{Experimental design}

Forty-eight animals were used for study; sixteen for high stocking; sixteen bucks at low stocking and sixteen not transported considered as control. The animals were stocked using a standard (low stocking rate) which conformed to the Animal Disease Control Act of 1988 of Nigeria and is in agreement with standard international regulations for transportation of goats and high stocking rate.

\section{Administration of ascorbic acid}

Ascorbic acid oral tablets Spartan ${ }^{\circledR}-\mathrm{C}$ (Agbara Drug Company, Lagos, Nigeria). The dose ascorbic acid administered orally was $300 \mathrm{mg} / \mathrm{kg}$ deduced from previous studies of Minka and Ayo, (2010); Biobaku, et al. (2016b). All animals transported at high and low stocking were administered with ascorbic acid. Ascorbic acid was orally administered at the beginning of the experimental journey Sokoto and at Jebba mid-way in to the journey.

\section{Loading, stocking, experimental journey, and ethics}

Before embarking on the experimental journey a health certificate was obtained from the Veterinary unit of Ministry of Forestry and Animal Health of Sokoto State, Nigeria. This was done to ensure strict adherence to guidelines stipulating animal transportation welfare by road as previously adopted by Minka and Ayo, (2010). The animal at low stocking rate were stocked at $0.30 \mathrm{~m}^{2}$ per animal; while those at high stocking were stocked at $0.15 \mathrm{~m}^{2}$ per animal using the method previously described by Biobaku et al. (2016a)

\section{Blood collection, haematological and biochemical analysis}

Blood sample was collected from the animals preloading at Sokoto, when resting the animal's midway at the veterinary quarantine post and at off loading from the truck at Abeokuta. A 21 gauge needle and syringes were used in blood collection from the jugular vein after ensuring asepsis by disinfecting the skin using methylated spirit of $10 \%$ concentration. Five milliliters of blood was collected in lithium heparin and EDTA bottles.

Assessment of full blood count was carried out using the method previously described by Schalm and Jain, (1986). Other erythrocytes parameters determined were; red blood cell count (RBC), erythrocytes sedimentation rate (ESR), haemoglobin concentration $(\mathrm{Hb})$, packed cell volume (PCV) and erythrocytes indices such; MCV, $\mathrm{MCH})$, mean and MCHC using the method Schalm and Jain, (1986).Total white blood cell, differential count and the neutrophils-lymphocytes ratio $(\mathrm{N}: \mathrm{L})$ were also determined using the methods previously adopted by Biobaku et al.(2016a). Randox ${ }^{\circledR}$ commercial test kits (made in England) were used to in the assessment of biochemical parameters using standard spectrophotometeric procedures. These are; alanine aminotransferase (ALT), aspartate aminotransferase (AST).Glucose was determined using glucometer (Roche Diagnostics Germany), cholesterol, and total protein using standard procedures. The electrolytes $\left(\mathrm{Na}^{+}, \mathrm{Ca}^{2+}, \mathrm{Mg}^{2+}, \mathrm{K}^{+}\right.$and $\left.\mathrm{Cl}^{-}\right)$ were analysed using commercial test kit (Randox ${ }^{\circledR}$, England).Antioxidative stress markers assessed are glutathione-S-transferase using the method of Habig et al. (1974); Superoxide dismutase as previously adopted by Zhou et al. (1986); malondialdehyde enzyme using thiobarbituric acid method Buege and Aust, (1978) and as adopted by Mohammad et al. (2007). Thyroid hormones; triiodothyronine T3 and tetraidothyronine T4 were also assayed with Biorex test kit (Biorex Diagnostics limited, United Kingdom) using ELISA as previously adopted by Muzzaffar and Gharib (1998).

\section{Statistical analysis}

The statistical sum of means of biochemical parameters at the three phases of the experimental journey .Means of values at different phases were compared at transported animals at high and low stocking rate were compared using ANOVA. The soft ware package used was SPSS version 16 and $\mathrm{P}<0.05$ was considered significant. 
Evaluating stress amelioration of oral vitamin c in bucks

\section{RESULTS AND DISCUSSION}

Results in tables 1, 2 and 3 present the effect of ascorbic acid and stocking density on biochemical, electrolytes, stress markers and thyroid hormones. There was a significant increase in AST in the low stocking group $(262.66 \pm 60.0 \mathrm{IU} / \mathrm{L})$ compared to the high stocking group $(198.03 \pm 95.43 \mathrm{IU} / \mathrm{L})$ and the normal non treated non transported group. No significant $(\mathrm{P}>0.05)$ changes in the electrolytes and anti-oxidative stress markers were observed in all treated groups compared to the control as presented in tables 2 and 3.

The haematological parameters of Sahel bucks had significant $(\mathrm{P}<0.05)$ increase in the erythrocytes sedimentation rate in group of low stocking rate $(7.41 \pm 2.06 \mathrm{~mm} / \mathrm{hr})$ when compared to the high stocking group $(6.42 \pm 1.75 \mathrm{~mm} / \mathrm{hr})$. Other erythrocytes parameters and indices showed no significant changes as shown in table 4. In table 5 however, there were significantly $(\mathrm{P}<0.05)$ increased in percentages of neutrophils at high stocking rate; while the lymphocytes, and eosinophils significantly $(\mathrm{P}<0.05)$ increased at low stocking rates. Neutrophilslymphocytes ratio and monocytes significantly $(\mathrm{P}<0.05)$ decreased at low stocking.

Table 1. Effect of stocking density on some biochemical parameters of Sahel bucks pretreated with ascorbic acid $(300 \mathrm{mg} / \mathrm{kg})$ and exposed to long of road stress

\begin{tabular}{lccc}
\hline Parameters & \multicolumn{3}{c}{ Stocking Rate } \\
\cline { 2 - 4 } & $\begin{array}{c}\text { Low Stocking rate } \\
(\text { Mean } \pm \text { SD) }\end{array}$ & $\begin{array}{c}\text { High Stocking rate } \\
(\text { Mean } \pm \text { SD) }\end{array}$ & $\begin{array}{c}\text { (Control) } \\
(\text { Mean } \pm \text { SD) }\end{array}$ \\
\hline ALT $(\mathrm{IU} / \mathrm{l})$ & $96.10 \pm 13.00$ & $110.74 \pm 44.96$ & $122.85 \pm 8.50$ \\
AST $(\mathrm{IU} / \mathrm{l})$ & $262.66 \pm 60.01^{\mathrm{a}}$ & $198.03 \pm 75.43^{\mathrm{c}}$ & $225.07 \pm 24.60^{\mathrm{b}}$ \\
Glucose $(\mathrm{mg} / \mathrm{dl})$ & $76.62 \pm 16.64$ & $69.44 \pm 19.87$ & $74.40 \pm 4.90$ \\
Cholesterol $(\mathrm{mg} / \mathrm{dl})$ & $87.44 \pm 43.83$ & $87.80 \pm 26.13$ & $96.19 \pm 17.60$ \\
Protein $(\mathrm{g} / \mathrm{l})$ & $73.56 \pm 10.03$ & $70.37 \pm 8.90$ & $72.39 \pm 5.99$ \\
\hline
\end{tabular}

Means bearing different superscripts abc along the same row differ significantly $(\mathrm{P}<0.05)$

Table 2. Effect of stocking density on Serum electrolytes parameters of Sahel bucks pretreated with ascorbic acid $(300 \mathrm{mg} / \mathrm{kg})$ and exposed to long road transportation stress

\begin{tabular}{lccc}
\hline Parameters & \multicolumn{3}{c}{ Stocking rate } \\
\cline { 2 - 4 } & $\begin{array}{c}\text { Low Stocking rate } \\
(\text { Mean } \pm \text { SD) }\end{array}$ & $\begin{array}{c}\text { High Stocking rate } \\
(\text { Mean } \pm \text { SD) }\end{array}$ & $\begin{array}{c}\text { (Control) } \\
(\text { Mean } \pm \text { SD) }\end{array}$ \\
\hline $\mathrm{Ca}^{++}(\mathrm{mg} / \mathrm{dl})$ & $9.33 \pm 0.53$ & $9.14 \pm 0.43$ & $9.24 \pm 0.42$ \\
$\mathrm{Mg}^{++}(\mathrm{mg} / \mathrm{dl})$ & $2.58 \pm 0.50$ & $2.73 \pm 0.57$ & $2.65 \pm 0.17$ \\
$\mathrm{Na}^{+}(\mathrm{mg} / \mathrm{dl})$ & $148.47 \pm 11.51$ & $152.22 \pm 11.02$ & $147.05 \pm 3.18$ \\
$\mathrm{~K}^{+}(\mathrm{mg} / \mathrm{dl})$ & $6.93 \pm 2.07$ & $5.36 \pm 1.50$ & $6.03 \pm 0.46$ \\
$\mathrm{Cl}^{-}(\mathrm{Mmol} / \mathrm{L})$ & $115.73 \pm 35.62$ & $112.5 \pm 35.62$ & $101.02 \pm 5.96$ \\
\hline
\end{tabular}

$\mathrm{P}<0.05$ is considered significant

Table 3. Effect of stocking rate on antioxidative stress markers and thyroid hormones of Sahel bucks pretreated with ascorbic acid $(300 \mathrm{mg} / \mathrm{kg})$ exposed to long road transportation stress

\begin{tabular}{lccc}
\hline Parameters & \multicolumn{3}{c}{ Stocking rate } \\
\cline { 2 - 4 } & $\begin{array}{c}\text { Low Stocking rate } \\
(\text { Mean } \pm \mathrm{SD})\end{array}$ & $\begin{array}{c}\text { High Stocking rate } \\
(\text { Mean } \pm \mathrm{SD})\end{array}$ & $\begin{array}{c}(\text { Control) } \\
(\text { Mean } \pm \mathrm{SD})\end{array}$ \\
\hline $\mathrm{GST}\left(\mu \mathrm{l} / \mathrm{ml}^{-1}\right.$ & $1.23 \pm 0.53$ & $1.44 \pm 0.43$ & $1.40 \pm 0.12$ \\
$\mathrm{MDA}\left(\mathrm{M}^{-1} \mathrm{Cm}^{-1}\right)$ & $0.11 \pm 0.11$ & $0.09 \pm 0.080$ & $0.08 \pm 0.03$ \\
$\mathrm{SOD}(\mathrm{Iu} / \mathrm{l})$ & $39.38 \pm 16.80$ & $39.31 \pm 16.60$ & $44.64 \pm 4.12$ \\
$\mathrm{~T}_{4}(\mu \mathrm{g} / \mathrm{dl})$ & $7.05 \pm 7.21$ & $7.90 \pm 7.1$ & $6.55 \pm 1.54$ \\
$\mathrm{~T}_{3}(\mathrm{ngl} / \mathrm{ml})$ & $2.83 \pm 1.42$ & $2.75 \pm 1.23$ & $2.65 \pm 0.59$ \\
\hline
\end{tabular}

$\mathrm{P}<0.05$ is considered significant 


\section{K. T. Biobaku and others}

Table 4. Effect of stocking density on erythrocytes and erythrocytic indices of Sahel bucks pretreated with ascorbic acid $(300 \mathrm{mg} / \mathrm{kg})$ exposed to long road transportation stress

\begin{tabular}{lccc}
\hline Parameters & \multicolumn{3}{c}{ Stocking rate } \\
\cline { 2 - 4 } & $\begin{array}{c}\text { Low Stocking rate } \\
(\text { Mean } \pm \text { SD) }\end{array}$ & $\begin{array}{c}\text { High Stocking rate } \\
(\text { Mean } \pm \text { SD) }\end{array}$ & $\begin{array}{c}\text { (Control) } \\
(\text { Mean } \pm \text { SD) }\end{array}$ \\
\hline RBC X $\left(10^{6} / \mu \mathrm{l}\right)$ & $10.77 \pm 3.23$ & $11.39 \pm 2.47$ & $11.30 \pm 0.64$ \\
PCV $(\%)$ & $26.80 \pm 5.04$ & $26.74 \pm 3.63$ & $28.83 \pm 0.84$ \\
ESR $(\mathrm{mm} / \mathrm{hr})$ & $7.41 \pm 2.06^{\mathrm{b}}$ & $6.42 \pm 1.75^{\mathrm{c}}$ & $11.26 \pm 0.67^{\mathrm{a}}$ \\
$\mathrm{Hb}(\mathrm{g} / \mathrm{dl})$ & $8.76 \pm 1.72$ & $8.85 \pm 1.08$ & $7.19 \pm 0.39$ \\
$\mathrm{MCHCH}(\mathrm{g} / \mathrm{dl})$ & $32.78 \pm 5.40$ & $33.68 \pm 5.44$ & $34.12 \pm 1.2$ \\
$\mathrm{MCH}(\mathrm{pg})$ & $8.93 \pm 2.15$ & $9.33 \pm 2.91$ & $8.53 \pm 3.04$ \\
$\mathrm{MCV}(\mathrm{fl})$ & $27.07 \pm 5.78$ & $26.84 \pm 7.26$ & $27.36 \pm 9.29$ \\
\hline
\end{tabular}

Means bearing different superscripts ab along the same row differ significantly $(\mathrm{P}<0.05)$

Table 5. Effect of stocking rate on Leucocytes of Sahel bucks pretreated with ascorbic acid (300mg) exposed to long road transportation stress

\begin{tabular}{lccc}
\hline Parameters & \multicolumn{3}{c}{ Stocking } \\
\cline { 2 - 4 } & $\begin{array}{c}\text { Low Stocking rate } \\
(\text { Mean } \pm \text { SD) }\end{array}$ & $\begin{array}{c}\text { High Stocking rate } \\
(\text { Mean } \pm \text { SD) }\end{array}$ & $\begin{array}{c}\text { Control } \\
(\text { Mean } \pm \text { SD) }\end{array}$ \\
\hline WBC $(\mathrm{X} \mathrm{10} / \mu 1)$ & $1.15 \pm 0.42$ & $1.26 \pm 0.55$ & $1.15 \pm 0.89$ \\
Neutrophils $(\%)$ & $29.85 \pm 5.27^{\mathrm{b}}$ & $34.52 \pm 4.61^{\mathrm{a}}$ & $29.10 \pm 1.28^{\mathrm{b}}$ \\
Lymphocytes (\%) & $67.74 \pm 6.34^{\mathrm{a}}$ & $62.88 \pm 5.42^{\mathrm{b}}$ & $62.20 \pm 1.26^{\mathrm{b}}$ \\
N:L & $0.45 \pm 0.12^{\mathrm{a}}$ & $0.55 \pm 0.12^{\mathrm{b}}$ & $0.50 \pm 0.03^{\mathrm{b}}$ \\
Eosinophils (\%) & $1.70 \pm 1.89^{\mathrm{b}}$ & $1.17 \pm 1.50^{\mathrm{b}}$ & $2.50 \pm 0.28^{\mathrm{a}}$ \\
Basophils (\%) & $0.81 \pm 1.46$ & $0.52 \pm 0.97$ & $1.10 \pm 0.24$ \\
Monocytes (\%) & $0.55 \pm 1.39^{\mathrm{b}}$ & $0.67 \pm 1.30^{\mathrm{a}}$ & $0.65 \pm 0.02^{\mathrm{a}}$ \\
\hline
\end{tabular}

Means bearing different superscripts ab along the same row differ significantly $(\mathrm{P}<0.05)$

Ascorbic acid at $300 \mathrm{mg} / \mathrm{kg}$ influenced the AST inconsistently at different stocking rates. This could be due to the long term effect of stress which the animals were exposed. This gives an insight that the ascorbic acid at $300 \mathrm{mg} / \mathrm{kg}$, administered did not endogenously ameliorate the depleted cellular endogenous antioxidant. Ascorbic acid decreased the AST at high stocking and the decrease was not evident in the low stocking in spite the stocking rate. It is evident that ascorbic acid counteracted the hepatocellular damage that resulted from the adverse effect of reactive oxygen species due to stress. The ascorbic acid therefore, influenced the AST irrespective of the stocking. We speculate that insufficient supplementation with ascorbic acid could aid the progression in the production pro-oxidants that would subsequently increase stress and further cause the production of reactive oxygen species (ROS) and nitrogen oxygen species (NOS) respectively. This might be associated with increased AST at the low stocking. Since there is dearth of information on stocking rate and therapeutic intervention in stress of road transportation, no categorical statement could be made as the main stay for this outcome from this intervention. But ascorbic acid could be associated with cytoprotective and antioxidative property. The aforementioned evidences and inconsistency in dynamics in the AST; could also be as a result of species factor in liver enzymes of small ruminants as previously observed by Chauhan and Agarwal, (2006). The ESR increase at low stocking could be associated to the cytoprotective effect of ascorbic acid on the erythrocytes. This could also be associated with ascorbic acid protecting against fragility of the erythrocytes; due to the ROS mopping effect of ascorbic acid. The integrity of the cell membrane maintenance and stability of the membrane could explain the changes of ESR as against the high stocking which are exposed to more stress hence the decreased effect of ESR.

The lymphocytes and the eosinophils increased after the use of ascorbic acid at low stocking. This observation is in agreement with the findings of Minka and Ayo, (2010). This signifies the immunomodulation of ascorbic acid which promoted effective attenuation of long term stress that could predispose to decrease in the cell 


\section{Evaluating stress amelioration of oral vitamin c in bucks}

mediated immunity. The low stocking in the course of supplementation with ascorbic acid at $300 \mathrm{mg} / \mathrm{kg}$ could be considered efficacious, in relieving stress of transportation in bucks and this was reflected on this leucocytes indices. The lymphocytes and eosinophils increased due the effect of ascorbic acid at low stocking rate. In the same vein the neutrophils which are the first line in the cell mediated immune response were prompted due to the immunomodulatory effect of ascorbic acid at high stocking rate. The finding in this study is in line with the previous findings of Minka and Ayo, (2011). This may indicate that the animals at high density stocking were subjected to more stress than those in the low stocking rate, but due to the immunodulatory effect of ascorbic acid it enhanced the first line cell mediated immunity in the stressed animals. The antistress property of ascorbic acid as observed on the neutrophils-lymphocytes ratio was favorable at low stocking under the influence of ascorbic acid which would aid physiological adaptation. Eosinopenia as a result of transportation stress in goats was also ameliorated by ascorbic acid at low stocking rate. This result suggests that most differential percentages of various white blood cells would be improved upon if the animals are treated and transported using the standard stocking. It could also be inferred that the condition of the animals treated was improved upon nutritionally by the usage of the ascorbic acid. The general adaptive syndrome associated with long term transportation stress which is detrimental to the homeostasis was counteracted by the therapeutic supplementation of ascorbic acid. The ascorbic acid would have also improved the intermediary metabolic pathway which would also be an advantage to the physiology of the animal. This could be beneficial in the prevention of stress induced syndrome. The ascorbic acid therefore, prompted the cell mediated immunity; by immunomodulation through the improvement of cell mediated immunity was seen to be more pronounced in the animals transported at low stocking rate. This ascorbic acid was also associated with providing supplemental ascorbate and sustaining endogenously available antioxidant present in the cell sequel to depletion due to production of prooxidants produced as a result of stress. The efficacy of this dose could be supports recent findings of Biobaku et al. (2016b) in which the dose of $300 \mathrm{mg} / \mathrm{kg}$ improved chevon quality in bucks subjected to stress of transportation. Furthermore speculation could be made that the low stocking rate would have caused a decline in the adrenaline and the detrimental surge of cortisol, which would result in the increase in the cellular components of immunity. The animals at high stocking rate might have observed an increase in the surge of cortisol and adrenaline more than those at low stocking. This probably might be the cause of the outcome of the differentials counts in animals in at the two stocking rates.

Conclusively, ascorbic acid ameliorated transportation stress in animal when standard stocking is enforced and this gives avenue for administration of ascorbic acid twice in long journeys at intervals while resting the animals. Thus, giving room for the animals to rest and adapt better to counteract the general adaptive syndrome during a long journey.

\section{ACKNOWLEDGEMENTS}

The authors wish to appreciate N. B. Yasir, Ibrahim and Mr. and Mrs. Abdul Rahman, for assisting during the experimental journey from Sokoto and all through the study.

\section{REFERENCES}

1. Ayo JO, Minka NS and Mamman M (2006). Excitability scores of goats administered ascorbic acid and transported during hot-dry conditions. Journal of veterinary sciences 7: 127-131.

2. Bender DA (1992). Ascorbic acid Nutritional Biochemistry of the Vitamin. $2^{\text {nd }}$ edn., New York: Press, Cambridge University, New York

3. Biobaku KT, Jibir M, Onifade KI, Ismaila MS, Odetokun AI and Agaie BM (2016b). Ascorbic acid supplementation improves the quality of meat and characteristics in Sahel bucks exposed long distance road transportation. Alexandria Journal of Veterinary Medicine 5: 24-30.

4. Biobaku KT, Agaie BM, Onifade KI, Odetokun IA, Okediran BS, Ameen SA, Ismaila MS Adam M and Raji LO (2016a). Effects of xylazine on physiological and biochemical parameters of Sahel bucks exposed to twenty-eight hours road transportation. Sokoto Journal of Veterinary Sciences 14: 43-52.

5. Buege JA and Aust SD (1978). Microsomal Lipid Peroxidation Methods. Enzymology 52: 302-305.

6. Chauhan RS and Agarwal DK (2006). Biochemical and Haematological analysis In: Veterinary Clinical and laboratory diagnosis $2^{\text {nd }}$ ed. Jaypee publishers, India. 


\section{K. T. Biobaku and others}

7. Haibig WH, Pabst MJ and Jakoby WB (1974). Determination of Gluthatione-S transferase. Journal of Biology and Chemistry 249: 7130-7139.

8. Hidiroglou M, Batra TR and Zhao X (1997).Comparison of Vitamin C bioavailability after multiple or single oral dosing of different formulations in sheep. Reproductive Nutrition and Development 37: 443-448.

9. Minka NS and Ayo JO (2010). Serum biochemical activities and muscular soreness in transported goats administered with ascorbic acid during the hot-dry season. European journal of Transitional Myology-Basic Applied Myology 1: 193-203.

10. Mohammed A, George L and Mustapha FL (2007). Exercise decreases oxidative stress and Inflammation and restores renal dopamine D receptor function in rats. American Journal of Physiology and Renal Physiology 293: 914-919.

11. Muzzaffari EL and Gharib H (1998). Thyroxin suppressive therapy in Patients with nodular thyroid disease. Annuals of Internal Medicine 128: 386-394.

12. Nakano, K. and Suzuki, S. (1984). Stress-Induced changes in the levels of ascorbic and histamine in rats. Journal of Nutrition 114: 1602-1608.

13. Schalm S and Jain NC (1986).Veterinary Haematology, 4th edition Leafabriger, Philadephia 564-574.

14. Zhou D, Kusnecophv AW, Shurin MR, Depaoli M and Rabin BS (1986). Exposure to physical and psychological stressors alleviates plasma interleukin-6 relationship to physical and psychological to activation of hypothalamicpituitary-adrenal axis. Endocrinology 133: 2523-2530.

15. Zulkifli I, MT, Che-Norma CH and TC Chong (2000). Heterophil to hymphocyte ratio and tonic Immobility reactions to Pre-slaughter handling in broiler chickens treates with ascorbic acid. Poultry Science 79: 402-406. 